\title{
Design Responsibility and Sustainability in Education
}

\author{
Ayman Fathy Ashour \\ College of Fine Arts and Design, University of Sharjah, Sharjah 27272, United Arab Emirates
}

Corresponding Author Email: afathy@sharjah.ac.ae

https://doi.org/10.18280/ijdne.150117

Received: 19 August 2019

Accepted: 8 February 2020

\section{Keywords:}

responsible design, sustainable design, sustainable design education

\begin{abstract}
Preparing students for a real-world profession is an essential element of the design education process. These students often question their abilities and power to successfully join the industry, especially when it comes to introducing innovative and sustainable design solutions. This article discusses integrating the concept of design responsibility into design education, thus instructing and encouraging students to become responsible and sustainability-oriented designers. Current research recommends inter- and multi-disciplinary learning approaches to achieve such integration, further arguing for the value of teaching design responsibility in inspiring design students to adopt sustainable design thinking as a means of improving the industry. Responsible design solutions should follow a logical, sequential process to create healthy, functional, comfortable, and sustainable designs without compromising aesthetic factors-all while meeting the client's needs, budget, schedule, and design vision.
\end{abstract}

\section{INTRODUCTION}

Despite increasingly limited resources, the world has experienced steady population growth for centuries. Recently, concerns about climate change have skyrocketed across the globe, coupled with scientific evidence for the adverse effects of greenhouse gases on the environment. Consequently, a greater awareness of sustainable practices and their importance is needed [1]. Conserving environmental resources has social, cultural, physical, and economic impacts, including the ability to sustain lifestyle requirements, a healthy economy, reduced global warming, and decreased toxic gas emissions [2]. This has sparked much dialogue on controlling consumption and sustaining natural resources to save our planet.

Sustainability has been recognized as a significant issue in many design fields due to the extensive resources needed in actualizing designs. Designers have a moral responsibility to help protect, preserve, and restore the global ecosystem [2]. Sustainable practices refer to actions that lessen environmental impacts and create a healthy environment [3].

This increased focus on environmental problems caused by highly consumerist societies has also spread to the field of design education, in which sustainability courses are increasingly common [4]. However, sustainable design education needs more development. It has been suggested that, despite sustainable design education being now considered a required theme of many design education programs, the attention inclines to be on environmental issues, whereas design responsibility issues are not given the same care [5]. Hence, the present paper argues that teaching design students the necessary knowledge and skills of sustainable design might not be enough to reach the ultimate goal of environmental conservation. Maintaining focus on knowledge and skills only for creating sustainable design solutions is problematic, as this does not ensure that design students will be successful in real-world sustainable applications. To include sustainability into their designs, students must also learn and practice design responsibility as well as be capable of convincing diverse stakeholders to backing sustainable design.

In this paper, the term 'sustainable' is used to refer to design solutions, while the term 'responsible' is used to refer to a characteristic of designers. 'Design responsibility' refers to conduct; in this case, when creating sustainable designs, the designer needs to consider the effects of such designs in different dimensions, including economic, social, and environmental.

\section{DESIGN RESPONSIBILITY AND ETHICS}

Ethics in design can be linked to Aristotelian and Kantian views, between which the Kantian perspective is more related to codes of professional practice. This can be compared with virtue ethics, which emphasizes the moral character of a person, and utilitarianism ethics, which focuses on the outcomes of an action [6]. The Sartrean existentialist perception of ethics can be used as design ethics fundamental. The main measure for judging ethical actions is based on facing freedom genuinely. The designer's ethical character in a Sartrean perspective is found in being conscious of their human condition and acknowledging and practicing their freedom [6].

However, sustainability has arguably integral ethics that implies communal choices on the society level. That is, sustainability can only be achieved if most society members believe in its importance. To achieve sustainability, society as a whole must adopt a common acceptance to pursue a sustainable community [7].

Nevertheless, virtue ethics may be considered for a sustainable design education model. Under the concept of virtue ethics, an important approach is Aristotle's ethos, which is one of three modes of persuasion described by Aristotle as 
an element of an argument. Ethos is a Greek word that means "character" and serves the purpose of determining the credibility one has in order to persuade the reader on a given topic being discussed. According to Aristotle, ethos are: phronesis, areté, and eunoia, where phronesis refers to practical skills, areté refers to an ethically right individual, and eunoia refers to the goodwill that a presenter promotes with their audience. The values of phronesis, areté, and eunoia all add up to generate the meaning of ethos. Obviously, it brings into perspective many different values of human beings that are taught throughout a lifetime. That is, lacking the knowledge and skills required to produce sustainable design solutions (phronesis), a designer will not be able to operate; without moral incentive, a designer will not pursue creating sustainable design solutions (areté); and lacking the ability of convincing stakeholders in sustainable design, a designer cannot achieve sustainable design solutions (eunoia) [8].

\section{DESIGN RESPONSIBILITY AND SUSTAINABLE DESIGN}

There are many philosophies with the purpose of addressing the current environmental problems, including sustainable design, ethical design, ecological design, green design, environmental design, environmentally conscious design, responsible design, design activism, social design, and environmental ethics which is the discipline in philosophy that studies the moral relationship of human beings to, and the value and moral status of, the environment and its non-human contents. However, we still need more work to accomplish effective sustainable solutions $[1,9]$.

Sustainable design solutions differ from conventional design solutions in their support of healthy environments as well as their rationalization of resource and energy consumption [10]. Responsible design solutions should follow a logical, sequential process for creating healthy, functional, comfortable, and sustainable solutions without compromising aesthetic factors-all while meeting the client's needs, budget, schedule, and design vision [11]. Designers should articulate sustainability in all aspects of their design solutions and ensure healthier indoor air quality by choosing materials and construction methods that prevent indoor air pollution, harmful chemical reactions, and gas emissions [10]. Designers should also be mindful of providing ecologically intelligent solutions that can reduce the rate of energy and water consumption, which include the use of durable products that do not require an excessive amount of maintenance and replacement [12]. Designers should further support the reduction of construction waste to lessen pollution and environmental damage, ensuring that the specified solutions and materials are from local or international certified sources [2].

To understand the requirements for responsible design, we must first discuss sustainable design. Sustainable design goes beyond environmental issues to consider social issues of design $[13,14]$. Sustainable development should address the requirements of the present without compromising the ability of future generations to meet their own needs. Sustainable design solutions can be achieved by following design practices such as creating design solutions that can easily adapt to changes in the users' activities, efficient energy conservation, and materials management [15]. Sustainable design generally places a strong focus on the environmental implications of design production; however, user behavior may also be affected by the goal of reducing negative impacts on the environment and society [16].

The United Nations discussed sustainable consumption and production as promoting resource and energy efficiency, sustainable infrastructure, and providing access to basic services, green and decent jobs and a better quality of life for all. Its implementation helps to achieve overall development plans, reduce future economic, environmental and social costs, strengthen economic competitiveness, and reduce poverty. However, many times, consumers go for irresponsible selections in relation to design output. Designers can be limited in their direction of design problems toward sustainable solutions due to the pressure of customer demands; but as designers attempt to introduce sustainable designs as a primary solution rather than an option their customers will likely be disaffected. Therefore, designers must also have the desire to promote sustainable designs as well as the ability to engage with clients with the understanding that a successful project should blend sustainability into each phase of the design process. The reason behind many unsustainable designs is likely not due to a complete absence of knowledge and skills that are required to produce sustainable design solutions but rather an unwillingness to do so or an inability to convince others to adopt sustainable design. That is why simply teaching design students to create sustainable solutions is not enough to raise the possibility that these solutions will be realized if students neither have nor develop the desire of adopting the idea $[17,18]$.

To address this issue, we may change design students' attitude toward sustainability by educating them about the consumption pattern consequences and how traditional unsustainable designs are contributing to increasing the problem. The absence of desire to pursue sustainable designs could be due to the failure to comprehend the negative effects of unsustainable designs and their role in increasing the problem. For example, recent warnings from the Intergovernmental Panel on Climate Change (IPCC) $[9,19]$ state that the effects of the current global warming are creating the need for designs to help shield from these negative effects. Thus, cultivating design responsibility concerns, an understanding of the effects of present designs practices and an awareness of how sustainable designs can be the solution.

To this end, design students are part of the system that produces design solutions, and they need to understand that the negative consequences of unsustainable design solutions also affect them. Cradle-to-cradle design is one of the approaches to sustainability that involve more comprehensive perceptions. This attitude has been supported by increased demand for sustainability in recent years that encourages and accelerates the shift of materials and producers toward sustainable principles and practices during the manufacturing process [20]. A fundamental trend toward education in sustainable design has been the shift from a fragmented knowledge base to integrative systems, which emphasizes inter-disciplinary approaches [21, 22]. The responsible designer must possess the aptitude to be considerate and responsive to the client's perspective to succeed in engaging them in sustainable design solutions [23, 24].

To gain consumer acceptance, designers must avoid disappointment in the proposed sustainable designs, thus implying that designers must produce sustainable designs with qualities that are equivalent to those of traditional designs. To avoid consumers associating sustainable design with 
inconvenience, high cost, or an aesthetically unpleasing appearance, designers must refrain from introducing sustainable design solutions that have less design value than an unsustainable design solution for the same problem [25, 26]. Producing effective sustainable design should not involve contradicting goals as aesthetics and ethics are inherently consistent [21]. Consequently, aesthetic education could contribute to ethical literacy among design students.

Finally, as designers have the power in influencing how we experience our environment, they must also be able to engage others in the pursuit of responsible design [27].

\section{EDUCATION FOR SUSTAINABLE DESIGN}

The importance of education in sustainable design has gained substantial acceptance recently. One outstanding initiative is the Decade of Education for Sustainable Development adopted by the United Nations General Assembly from 2005 to 2014 [28, 29]. There has been a methodological change to a systems approach in design instead of the problem approach. Designers act in a system approach rather than create isolated design solutions. One consequence is the necessity of increasing the ethical consciousness of design students through including design ethics education in design education programs [30, 31]. The reason behind education in sustainable design has been discussed as preparing students for transitions toward sustainability, which involves a significant change in perception away from that of consumerism. Current research is also linking this shift to an increasing need for the transformation of education overall $[3,30]$.

Dobson [32] argued that design educational curricula should enable students to explore sustainable problems. This includes a critical exploration of societal values. The involvement of students, faculty, and participants builds a case for design that stresses designers' roles toward responsible design for a wide range of causes. Students can derive their design activities from an ethical core and connect to a clearly defined set of environmental imperatives. Student involvement in the development of design briefs can set the stage for a more thoughtful, more grounded, and more integrated subsequent design process. The wider and more diverse set of ethical principles, tangible goals, and identified strategies must be addressed if projects are to reach the levels of regeneration necessary for a responsible design; for example, how design can support the idea of a better future for neglected community groups, and how far these caring design solutions can psychologically assist designers and support their involvement in their communities as active members, should be investigated further. Ultimately, this expanded design brief offers the opportunity for students to delve deeply into the ethical foundations of a project's guiding principles, aesthetic goals, and target budgets, to meet a project's ethical goals [33, 34].

Schön [35] refers to the appropriate design process as a reflective conversation with the situation. Reflective practice involves great awareness of the design situation and a capacity to introduce appropriate response consistently with the circumstances. The designer enters a constant conversation with the design situation, in so doing determining the situation; the situation then provides feedback to the designer. As such, reflective practice sufficiently addresses the complex nature of the design process, including the effects of design solutions on the environment and society in large, which is a concern of responsible design.

However, integrating a subject as complex as sustainability into design education presents some challenges to conventional pedagogy [36], thus requiring the involvement of inter- and multi-disciplinary approaches [37]. It may be needed to challenge traditional approaches of education and move toward new approaches for integrative learning [36]. Ashford [31] suggested integrating sustainable practice into engineering education, as many of today's unsustainable practices have their origins in traditional engineering solutions, which may lead to a better adoption of sustainability.

Numerous researches have been conducted on the integration of sustainability into design education, many of which suggest a model of sustainability, in which environmental, social, and economic are interrelated [31, 37]. Nevertheless, students tend to struggle once given complicated sustainability issues; they see sustainability to be related to environmental issues but not social and consequently seldom comprise design concepts addressing the social dimension [3]. Bakker et al. [38] argued that design thinking prepares students to deal with such situations, often characterized by uncertainties and multiple possible solutions. Learning process should be mediated through design thinking, such as identifying the associations between independent variables (e.g., problem-solving skills) and dependent variables (e.g., specific design solution) [39].

\section{CONCLUSIONS}

Gee [40] noted that existing educational practices adhere to obsolete pedagogical and learning theories, given their obsession with content. As such, schools continue to cultivate proficiency in more conventional subjects, such as reading and math, employing didactic approaches that can lead to learner disengagement. There is a need to move beyond these limited approaches and teach new skills that are educationally valuable.

Sustainable design education has to apply a comprehensive approach rather than just delivering the knowledge necessary to produce sustainable designs. Designers should always be aware that the world is continually changing and evolving, as the core of their work is to create new designs that meet current needs while accounting for future requirements. Because design aims to achieve human wellbeing, it is essential for designers to understand how the designs they create will affect those who consume them, as well as society and the environment at large. Designers have the ability to create meaning, spread information, and achieve positive change; therefore, it is vital that we teach design students to better understand the importance of sustainable design and prepare them to actively engage with real-world challenges.

However, despite the positive environmental and social impacts of this approach, design responsibility is not a prominent topic in current design education. Education is a cornerstone in the field of design, as it develops students' design knowledge and capabilities; hence, the emphasis should be on training students how to produce sustainable designs through a profound understanding of the current environment as well as social issues and how to involve all stakeholders in sustainable solutions. Finally, the question of how to offer design students a more comprehensive standpoint on sustainable design that utilizes inter and multi-discipline 
approaches opens the door for more argument.

\section{REFERENCES}

[1] Jones, L. (2008). Environmentally Responsible Design: Green and Sustainable Design for Interior Designers. John Wiley \& Sons: New Jersey.

[2] Tucker, L.M. (2014). Designing Sustainable Residential and Commercial Interiors: Applying Concepts and Practices. Fairchild: New York.

[3] Ruff, C.L., Olson, M.A. (2009). The attitudes of interior design students towards sustainability. International Journal of Technology and Design Education, 19(1): 6777. http://dx.doi.org/10.1007/s10798-007-9038-0

[4] Lofthouse, V. (2013). Social issues: Making them relevant and appropriate to undergraduate student designers. Design and Technology Education: An International Journal, 18(2): 8-23.

[5] Ramirez, M. (2007). Sustainability integration in industrial design education: A worldwide survey. Proceedings of Connected 2007: International Conference on Design Education, eds. C. Reidsema \& R. Zehner, University of NSW: Sidney, 1-5.

[6] d'Anjou, P. (2010). Beyond duty and virtue in design ethics. Design Issues, 26(1): 95-105. http://dx.doi.org/10.1162/desi.2010.26.1.95

[7] Fuad-Luke, A. (2009). Design Activism: Beautiful Strangeness for a Sustainable World, Earthscan: Sterling, VA.

[8] Garver, E. (1994). Aristotle's Rhetoric: An Art of Character, University of Chicago Press: Chicago.

[9] IPCC, Climate Change 2014: Impacts, Adaptation, and Vulnerability: Contribution of Working Group II to the Fifth Assessment Report of the Intergovernmental Panel on Climate Change, Cambridge University Press: Cambridge; New York, 2014.

[10] Yu, C. (2015). Healthy Indoor Environments for Sustainable Buildings: Design and Construction, Taylor \& Francis: London.

[11] Ceschin, F., Idil, G. (2016). Evolution of design for sustainability: From product design to design for system innovations and transitions. Design Studies, 47: 118-163. http://dx.doi.org/10.1016/j.destud.2016.09.002

[12] Spiegel, R., Meadows, D. (2010). Green Building Materials: A Guide to Product Selection and Specification (3rd ed.), John Wiley \& Sons: New Jersey.

[13] Lilley, D. (2009). Design for sustainable behaviour: Strategies and perceptions. Design Studies, 30(6): 704720. http://dx.doi.org/10.1016/j.destud.2009.05.001

[14] Chapman, J., Gant, N. (2007). Design Visionaries and Other Stories: A Collection of Sustainable Design Essays, Earthscan: Sterling, VA.

[15] Bhamra, T., Lofthouse, V. (2007). Design for Sustainability: A Practical Approach. Gower Publishing: Aldershot, UK.

[16] Bhamra, T., Lilley, D., Tang, T. (2011). Design for sustainable behaviour: Using products to change consumer behaviour. The Design Journal, 14(4): 427-445. http://dx.doi.org/10.2752/175630611X13091688930453

[17] Jelsma, J., Knot, M. (2002). Designing environmentally efficient services; A 'script' approach. The Journal of Sustainable Product Design, 2(3): 119-130. http://dx.doi.org/10.1023/B:JSPD.0000031031.20974.1 $b$

[18] Rodríguez, E., Boks, C. (2005). How design of products affects user behaviour and vice versa: The environmental implications. Proceedings of the 4th International Symposium on Environmentally Conscious Design and Inverse Manufacturing Ecodesign, IEEE: Piscataway, pp. 1-8.

[19] IPCC, Climate Change 2014: Mitigation of Climate Change: Contribution of Working Group III to the Fifth Assessment Report of the Intergovernmental Panel on Climate Change. Cambridge University Press: Cambridge; New York, 2014.

[20] McDonough, W., Braungart, M. (2002). Cradle to Cradle: Remaking the Way We Make Things. North Point Press: New York.

[21] Findeli, A. (2001). Rethinking design education for the 21st century: Theoretical, methodological, and ethical discussion. Design Issues, 17(1): 5-17. http://dx.doi.org/10.1162/07479360152103796

[22] Cassim, F. (2013). Hands on, hearts on, minds on: Design thinking within an education context. International Journal of Art \& Design Education, 32(2): 190-202. http://dx.doi.org/10.1111/j.1476-8070.2013.01752.x

[23] Smith, C.R. (2004). Ethos dwells pervasively: A hermeneutic reading of Aristotle on credibility. The Ethos of Rhetoric, ed. M.J. Hyde, University of South Carolina Press: Columbia, SC, 1-19.

[24] Oak, A. (2000). It's a nice idea, but it's not actually real: Assessing the objects and activities of design. Journal of Art and Design Education, 19(1): 86-95. http://dx.doi.org/10.1111/1468-5949.00205

[25] Ramirez, E. (2013). The consumer adoption of sustainability-oriented offerings: Toward a middle-range theory. Journal of Marketing Theory and Practice, 21(4): 415-428. http://dx.doi.org/10.2753/MTP10696679210405

[26] Ertekin, Z.O., Atik, D. (2015). Sustainable markets: Motivating factors, barriers, and remedies for mobilization of slow fashion. Journal of Macromarketing, 35(1):

53-69. https://doi.org/10.1177\%2F0276146714535932

[27] Berman, D.B. (2009). Do Good: How Designers Can Change the World. AIGA Design Press: Berkeley, CA.

[28] Lindley, J. (2010). Sustainability's relationship with Product Design Education: A sharing of the experience of teaching sustainability to Product Design students. ERSCPEMSU Conference, Delft, The Netherlands.

[29] Roorda, N. (2010). Successful strategies for ESD: Sailing on the winds of change. ERSCPEMSU Conference, Delft, The Netherlands.

[30] Cull, A.K. (2005). The Education of Undergraduate Product Designers in the Principles and Practice of Sustainable Design, Robert Gordon University: Aberdeen.

[31] Ashford, N.A. (2010). Major challenges to education for sustainable development: Can the current nature of institutions of higher education hope to educate the change agents needed for sustainable development? ERSCPEMSU Conference, Delft, The Netherlands.

[32] Dobson A. (2007). Environmental citizenship: Towards sustainable development. Sustainable Development, 15: 276-285. http://dx.doi.org/10.1002/sd.344

[33] Margolin, V. (2007). Design and the future of the human spirit. Design Issues, 23(3): 4-15. 
http://dx.doi.org/10.1162/desi.2007.23.3.4

[34] Sterling, S. (2004). Higher education, sustainability and the role of systemic learning. Higher Education and the Challenge of Sustainability, eds. P. Corcoran \& A. Wals, Kluwer: Dordrecht, 49-70. http://dx.doi.org/10.1007/0306-48515-X_5

[35] Schön, D.A. (1983). The Reflective Practitioner: How Professionals Think in Action. Basic Books, 1983.

[36] Fortuin, P.J., Bush, S.R. (2010). Educating students to cross boundaries between disciplines and cultures and between theory and practice. International Journal of Sustainability in Higher Education, 11(1): 19-35.

[37] Steiner, G., Posh, A. (2006). Higher education for sustainability by means of transdisciplinary case studies:
An innovative approach for solving complex, real world problems. Journal of Cleaner Production, 14(9-11): 877890. http://dx.doi.org/10.1016/j.jclepro.2005.11.054

[38] Bakker, C., Peck, D., Soboll, P., Tempelman, E. (2010). Living climate change: Design thinking and learning in complexity. ERSCPEMSU Conference, Delft, The Netherlands.

[39] Chiu, M.L. (2002). An organizational view of design communication in design collaboration. Design Studies, 23: $\quad 187-210 . \quad$ http://dx.doi.org/10.1016/S0142694X(01)00019-9

[40] Gee, J.P. (2005). What would a state of the art instructional video game look like? Innovate: Journal of Online Education, 1(6). 